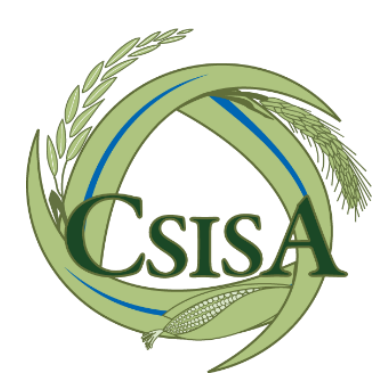

The Cereal Systems Initiative for South Asia (CSISA) is a researchfor-development partnership implemented jointly by five CGIAR institutions - the International Maize and Wheat Improvement Center (CIMMYT), International Food Policy Research Institute (IFPRI), International Livestock Research Institute (ILRI), International Rice Research Institute (IRRI) and World Fish - in close partnership with public and private sector organizations across South Asia.

\section{The Impact of Seed-Policy Reforms and}

\section{Intellectual Property Rights on Crop Productivity in India}

\author{
Deepthi E. Kolady, David J. Spielman and Anthony J. Cavalieri
}

September 2014

\section{Introduction}

Numerous studies have shown that the liberalization of seed market policies and stronger legal protection of intellectual property rights (IPR) can stimulate private investment in agriculture, especially crop genetic improvement. However, few studies have examined whether this translates into increased agricultural productivity. This study ${ }^{1}$ explores this question in the context of India, where policy reforms during the late 1980s opened the door to private investment in the seed market, and where more recent reforms have afforded private innovators with stronger IPR protections over plant varieties.

\section{Progressive Policy Reforms}

India's seed industry was entirely the domain of the public sector until the late 1980s, when two key pieces of legislation opened the door for private sector involvement. For the first time, the Industrial Licensing Policy of 1987 allowed large Indian companies (including companies having not more than 40 percent foreign ownership) to produce and sell seeds in India. This was followed by the New Policy for Seed Development of 1988, which relaxed seed trade norms within the country; reduced import restrictions on germplasm, seed and seed-processing equipment; and encouraged participation of foreign companies in the seed industry. These policies were reinforced by the New Industrial Policy of 1991, which allowed foreign direct investment in the seed industry.

These developments resulted in a rapid increase in private sector activity in the seed industry. The private sector focused on the higher-value segment of the seed market, particularly hybrids. Hybrids are attractive to the private sector because they effectively provide a biological protection for IPR - farmers must buy fresh seed every year to benefit from the increased yields of hybrids - allowing breeders to recoup their investments in cultivar development. The development and distribution of private 
hybrids resulted in significant yield increases for pearl millet, sorghum and maize in India's semi-arid tropics (Figure 1).

India's seed industry received a further boost beginning in 1995, when the country joined the World Trade Organization (WTO) and signed WTO's Trade-Related Aspects of Intellectual Property Rights (TRIPS) agreement. This agreement requires signatory countries to

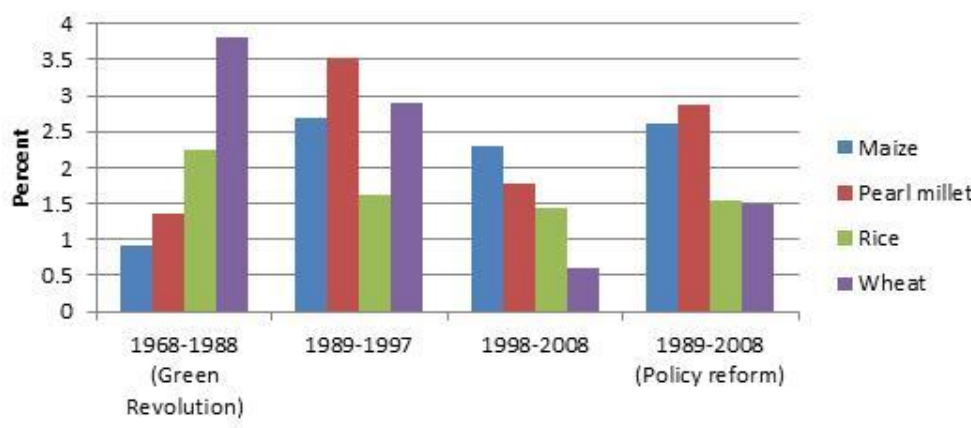

Figure 1: Yield growth rates for maize, pearl millet, rice and wheat in India, 1968-2008

provide IPR protection for new plant varieties. To meet this requirement, the Government of India enacted the Protection of Plant Varieties and Farmers' Rights (PPV\&FR) Act in 2001 and established the PPV\&FR Authority soon after. The Authority began processing applications for varietal protection in 2007. In 2008-09, 64 percent of the 460 applications for plant variety protection (PVP) received by the PPV\&FR Authority were from the private sector, again with a focus on crops in which hybrids are predominant, such as cotton, maize and rice.

Previous studies ${ }^{2}$ have shown that these policy reforms resulted in a marked increase in private sector investment and activity on hybrid crops (maize and pearl millet) but had much less impact on self-pollinated crops (rice and wheat). This suggests that while favorable policy changes combined with biological forms of IPR protection are essential to attracting private investment, these effects are very crop-specific. And these studies say little about the effect of policy changes on productivity per se.

The study outlines an empirical model to test the hypothesis that supportive policy changes and enforceable IPRs encourage greater private investment in the research, development and delivery of improved seed, ultimately leading to increases in yields realized by farmers. The model used data on yields since 1966 for maize, pearl millet, rice and wheat, together with data on rainfall and real farm harvest prices for each crop.

Study results showed that the policy reforms passed between 1987 and 1991 contributed significantly to increasing the yields of maize and pearl millet - the hybrid crops. In contrast, there was no evidence of policy having contributed to increasing the yields of rice and wheat, the selfpollinated crops. This indicates that policy reforms have crop-specific effects, and when considered alone, they are insufficient to attract private sector investment in plant breeding and the seed industry. This also indicates that some form of IPR protection, whether biological (as in the case of hybrids) or legal, is also required to provide sufficient incentives for private sector investment in crop improvement.

These results provide public policymakers and corporate decision-makers in South Asia with insights into the accumulated evidence on the relationships between seed-policy reforms, private investment in research and development (R\&D), and productivity growth in the agriculture sector. 
Results from this study indicate that the private sector is likely to contribute to revitalizing growth rates of rice and wheat yields only if some form of IPR protection (biological or legal) can be effectively implemented for these two crops.

Hybrids provided private firms a way to monetize the gains from innovation, and in the absence of sufficient legal IPR mechanisms, private firms will likely continue to invest in developing hybrids and conferring new traits on hybrids. This strategy holds promise in the case of rice, where hybrids are making inroads in India, though not without significant challenges.

In contrast, farmers in India buy less than 20 percent of the wheat seed planted each year, and wheat hybrids developed to date have performed poorly. This discourages investment in the further development of wheat hybrids; only one firm has released a commercial wheat hybrid cultivar in India to date. Thus, if the private sector is to contribute to raising the yield growth rate of wheat, the government will need to strengthen legal protection for IPRs, for example by enhancing the ability of the PPV\&FR Authority's capacity to enforce the PPV\&FR Act. This will also depend on the courts' ability to adjudicate fairly on infringement cases.

\footnotetext{
${ }^{1}$ Kolady, D.E., D.J. Spielman and A. Cavalieri. 2012. "The Impact of Seed Policy Reforms and Intellectual Property Rights on Crop Productivity in India." Journal of Agricultural Economics 63(2): 361-384.

${ }^{2}$ Gerpacio, R.V. (2003), "The Roles of Public Sector versus Private Sector in R\&D and Technology Generation: The Case of Maize in Asia." Agricultural Economics, 29 (2003): 319-330; Morris, M.L., Singh, R.P., and Pal, S., "India's Maize Seed Industry in Transition: Changing Roles for the Public and Private Sectors." Food Policy, Vol. 23 (1998) pp. 55-71; Pray, C.E., and Nagarajan, L., "Improving Crops for Arid Lands: Pearl Millet and Sorghum in India." in Spielman, D.J., and Pandya-Lorch, R. (eds.), "Millions Fed: Proven Successes in Agricultural Development." (Washington, D.C.: International Food Policy Research Institute, 2009); Pray, C.E., and Ramaswami, B., "Liberalization's Impact on the Indian Seed Industry: Competition, Research, and Impact on Farmers." International Food and Agribusiness Management Review Vol.2 (2001) pp. 407-420; Pray, C.E., Ramaswami, B. and Kelley, T., "The Impact of Economic Reforms on R\&D by the Indian Seed Industry." Food Policy Vol.26 (2001) pp. 587-598; Pray, C.E., Ribeiro, S., Mueller, R.A.E., and Rao, P.P., "Private Research and Public Benefit: The Private Seed Industry for Sorghum and Pearl Millet in India." Research Policy Vol. 20 (1991) pp. 315-324; Ramaswami, B. (2002), "Understanding the Seed Industry: Contemporary Trends and Analytical Issues." Indian Journal of Agricultural Economics Vol.57 (2002) pp. 417-429.
}

\section{Author Details}

Deepthi E. Kolady was Visiting Fellow, Department of International Programs at Cornell University when she conducted this research. She is currently an Assistant Director in the Department of International Programs at Cornell University, USA.dek28@cornell.edu

David J. Spielman is a Senior Research Fellow in the Environment and Production Technology division, International Food Policy Research Institute, Washington, DC, USA.

Anthony J. Cavalieri was an independent consultant when he conducted this research. He is currently an Interim Deputy Director, Crops, Bill and Melinda Gates Foundation in Seattle, Washington. 